\title{
Article \\ Molecular Diet Analysis of Adélie Penguins (Pygoscelis adeliae) in the Ross Sea Using Fecal DNA
}

\author{
Nazia Tabassum ${ }^{1,+}{ }^{\mathbb{D}}$, Ji-Hyun Lee ${ }^{2,+}+\mathbb{D}$, Soo-Rin Lee ${ }^{1}$, Jong-U Kim ${ }^{3}$, Hyun Park ${ }^{4}\left(\mathbb{D}\right.$, Hyun-Woo Kim ${ }^{2,5}, * \mathbb{D}$ \\ and Jeong-Hoon $\mathrm{Kim}^{3, *(\mathbb{D})}$
}

1 Industry 4.0 Convergence Bionics Engineering, Pukyong National University, Busan 48513, Korea; naziaat110@gmail.com (N.T.); srlee090@pukyong.ac.kr (S.-R.L.)

2 Department of Marine Biology, Pukyong National University, Busan 48516, Korea; jhlee208@pukyong.ac.kr

3 Division of Life Science, Korea Polar Research Institute, Incheon 21990, Korea; wildlife@kopri.re.kr

4 Department of Biotechnology, Korea University, Seoul 02841, Korea; hpark@korea.ac.kr

5 Marine Integrated Biomedical Technology Center, National Key Research Institutes in Universities, Pukyong National University, Busan 48513, Korea

* Correspondence: kimhw@pknu.ac.kr (H.-W.K.); jhkim94@kopri.re.kr (J.-H.K.)

+ Co-first author, these authors contributed equally to this work.

check for

updates

Citation: Tabassum, N.; Lee, J.-H.; Lee, S.-R.; Kim, J.-U.; Park, H.; Kim, H.-W.; Kim, J.-H. Molecular Diet Analysis of Adélie Penguins (Pygoscelis adeliae) in the Ross Sea Using Fecal DNA. Biology 2022, 11, 182. https://doi.org/10.3390/ biology11020182

Academic Editor:

Pierangelo Luporini

Received: 24 December 2021

Accepted: 21 January 2022

Published: 24 January 2022

Publisher's Note: MDPI stays neutral with regard to jurisdictional claims in published maps and institutional affiliations.

Copyright: () 2022 by the authors Licensee MDPI, Basel, Switzerland. This article is an open access article distributed under the terms and conditions of the Creative Commons Attribution (CC BY) license (https:// creativecommons.org/licenses/by/ $4.0 /)$.
Simple Summary: The diet of Adélie penguins, Pygoscelis adeliae, in the Ross Sea was studied applying quantitative polymerase chain reaction (qPCR) protocols to their feces. Two krill species (Euphausia superba and Euphausia crystallorophias) and notothenioid fish (mainly Pleuragramma antarctica and Pagothenia borchgrevinki) were among the most abundant components of the diet. The composition of the two krill species and notothenioid fish was found to be strongly related to the geographic characteristics of the Ross Sea.

Abstract: The diet of Adélie penguins, Pygoscelis adeliae, is a useful indicator in understanding the ecological conditions of their habitats. The diets of Adélie penguins were studied using metabarcoding and quantitative PCR (qPCR) analyses of fecal DNA from seven habitats along the Ross Sea region. Using metabarcoding analysis with dual universal primers (18Sv9 and miniFish), the overall diet composition and detailed information about piscine prey were clearly elucidated. It was found that two krill species (Euphausia superba and Euphausia crystallorophias) and notothenioid fish were the most abundant in the diets of Adélie penguins. Among the notothenioid prey, Pleuragramma antarctica (56.50\%) and Pagothenia borchgrevinki (18.21\%) were the two most abundant species. qPCR analysis showed a significant geographic difference in the composition of main prey. Penguins inhabiting outbound parts of the Ross Sea (Capes Adare (CA) and Duke of York Island (DY)) mainly preyed on E. superba, without any significant changes in prey composition. By contrast, those inhabiting the inbound parts of the Ross Sea (Edmonson Point (EP) and Inexpressible Island (II)) preyed on E. crystallorophias and notothenioid fish rather than E. superba. Compared with the outbound habitats, prey compositions for penguins inhabiting the inbound regions were significantly different year to year, which was presumably due to the food availability based on the annual environmental and meteorological conditions of the coastal region along with the inbound parts of the Ross Sea.

Keywords: Pygoscelis adeliae; Ross Sea; NGS; metabarcoding; diet analysis

\section{Introduction}

The Adélie penguin, Pygoscelis adeliae, is known to be the most abundant and widely spread penguin species in Antarctica, distributed along the entire coast of the continent [1]. As an omnivorous predator, it is regarded as a vital biomarker for ecological and environmental factors [2]. Thus, understanding the penguin's feeding ecology can provide basic information to establish models and plans for sustainability of the species in each habitat. Previous studies of the diets of Adélie penguins were conducted either directly via visual 
inspection [3-6] or indirectly via stable isotopes and fatty acid composition [7,8]. Based on the combination of direct and indirect methods, it is known that the main diet of Adélie penguins includes krill and notothenioid fish and glacial squid $[9,10]$.

Traditionally, penguin diets have been identified by the morphological classification of ingesta collected by a stomach flushing technique according to standard methods of the CCAMLR Ecosystem Monitoring Program (CEMP) (CCAMLR, 2014). However, these traditional methods have several limitations for long-term or frequent surveys, mainly because of the high cost and labor, limited accessibility to target species, the occasional adverse environmental impact on the site during sample collection, or administrative approval $[11,12]$. It is extremely difficult to identify partially digested prey to the species level, which is one of the main limiting factors in morphological diet studies. As DNA sequencing technology advanced, the metabarcoding technique was developed, in which the whole taxon within the sample can be analyzed immediately with relatively low cost and short analytic time using the next-generation sequencing (NGS) platform. Compared with traditional visual analysis of prey remains, much higher numbers of diet samples can be rapidly and accurately processed at relatively low cost and with less labor using metabarcoding analysis [13]. There have been several metabarcoding studies on the diets of Adélie penguins $[6,14,15]$. However, some of them used the remaining contents by the stomach-flushing technique, which made it challenging to obtain sufficient sample numbers for analysis. In addition, this technique may have adverse impacts on both the examined individuals and their habitats, occasionally causing death by post-traumatic shock or asphyxia following stomach flushing [16]. Alternatively, metabarcoding analysis of fecal DNA can be applied when it is difficult to access a predator's stomach contents $[6,15]$. However, such studies depend solely on a single marker, a short $18 \mathrm{~S}$ region, which makes it challenging to know the exact species name or precise quantitative value of each prey item.

We investigated the diets of Adélie penguins from seven habitats along the Ross Sea, Antarctica, by metabarcoding analysis of isolated fecal DNA, which was collected for three years (2017 to 2019). Dual universal primers (18Sv9 for eukaryotes and mini fish for fish taxa) were used for the metabarcoding analysis to obtain more precise information of the diets. In addition, quantitative polymerase chain reaction (qPCR) was applied for higher accuracy in quantitative analysis of the main prey items of Adélie penguins: notothenioid fish, Euphausia superba, and Euphausia crystallorophias. The results show geographic variability in prey items, which is related to their availability and abundance. These results can help to expand our knowledge of the relationship between penguin populations and environmental conditions in the Ross Sea.

\section{Materials and Methods}

\subsection{Sample Collection}

Fresh scat samples from individual Adélie penguins were collected from their breeding colonies in the Ross Sea Region Marine Protected Area, including Cape Adare (CA), Duke of York Island (DY), Cape Hallett (CH), Cape Wheatstone (CW), Mandible Cirque (MC), Edmonson Point (EP), and Inexpressible Island (II) (Figure 1 and Table 1). The size of Adélie penguin colonies in the area where the samples were collected varied from 1890 pairs at Edmonson Point to 227,000 pairs at Cape Adare (Table 1) [17,18]. Sample collections were conducted during the guard stage [19] in 3 consecutive breeding seasons, from December 2017 to January 2020. However, scat samples were collected only at $\mathrm{CH}$ and II for all 3 years, whereas 2- or 1-year samples were collected at the rest of the sites (Table 1). Except for samples collected at 3 sites (CA, CH, and II) in January 2020, all other scat samples were collected in December. At each sampling site, 11 scat samples were collected, with several exceptions: 5 at II in 2017, 7 at CW in 2018, and 10 at CH in 2017 (Table 1). Only freshly excreted unfrozen scat was collected around the nests, minimizing the impact on the penguins' incubation process and colonies. 


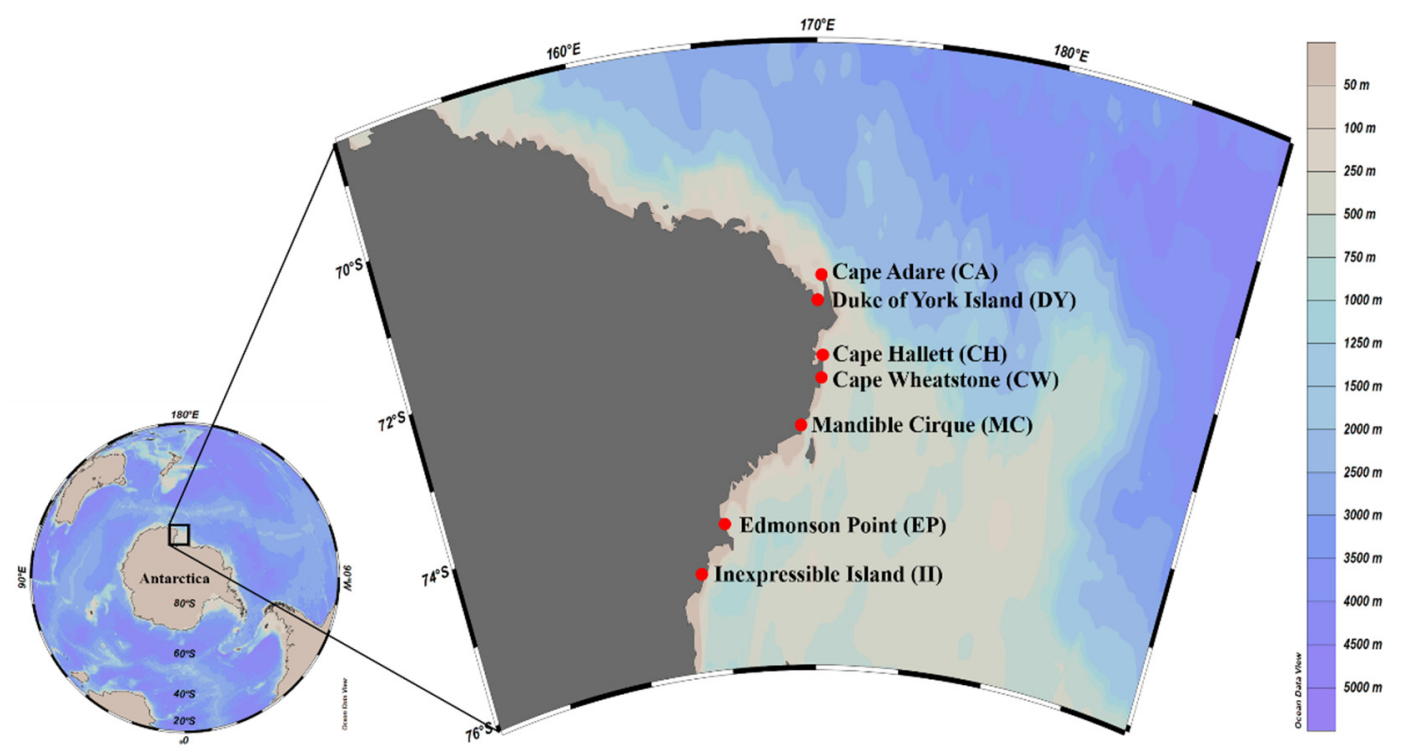

Figure 1. Sample sites for fecal DNA analysis in the Ross Sea region. Map view created by Ocean Data View software version 5.1.7 (Schlitzer, R., Ocean Data View, 2018, odv.awi.de, accessed on 23 December 2021).

Table 1. Details of collection of Adélie penguin (Pygoscelis adeliae) fecal samples used in this study.

\begin{tabular}{ccccccc}
\hline Site & GPS & Colony Size & $\mathbf{2 0 1 7}$ & $\mathbf{2 0 1 8}$ & $\mathbf{2 0 1 9}$ & Total \\
\hline Cape Adare (CA) & $71.3355^{\circ} \mathrm{S}, 170.1397^{\circ} \mathrm{E}$ & $227,000[17]$ & 0 & 11 & $11^{*}$ & 22 \\
Duke of York Island (DY) & $71.6197^{\circ} \mathrm{S}, 170.0600^{\circ} \mathrm{E}$ & $16,340[18]$ & 0 & 11 & 0 & 11 \\
Cape Hallett (CH) & $72.3166^{\circ} \mathrm{S}, 170.2166^{\circ} \mathrm{E}$ & $42,628[17]$ & 10 & 11 & $11^{*}$ & 32 \\
Cape Wheatstone (CW) & $72.5991^{\circ} \mathrm{S}, 170.2527^{\circ} \mathrm{E}$ & $2746[17]$ & 0 & 7 & 0 & 7 \\
Mandible Cirque (MC) & $73.1631^{\circ} \mathrm{S}, 169.1647^{\circ} \mathrm{E}$ & $16,837[17]$ & 11 & 0 & 11 & 22 \\
Edmonson Point (EP) & $74.3308^{\circ} \mathrm{S}, 165.1172^{\circ} \mathrm{E}$ & $1890[17]$ & 0 & 11 & 11 & 22 \\
Inexpressible Island (II) & $74.9000^{\circ} \mathrm{S}, 163.6500^{\circ} \mathrm{E}$ & $24,450[17]$ & 5 & 11 & $11^{*}$ & 27 \\
\hline Total & & & 26 & 62 & 55 & 143 \\
\hline
\end{tabular}

* Samples collected in January 2020.

\subsection{Fecal DNA Isolation}

Immediately after collection, the scat samples were put into 6 volumes of lysis buffer (50 mM Tris- $\mathrm{HCl} \mathrm{pH} \mathrm{8.0,} 500 \mathrm{mM} \mathrm{NaCl}$, and $50 \mathrm{mM}$ EDTA) and stored frozen at $-20^{\circ} \mathrm{C}$ until delivery to the laboratory for further analysis. Fecal DNA was extracted using the AccuPrep genomic DNA extraction kit (Bioneer, Daejeon, Republic of Korea) following the manufacturer's instructions. The frozen samples in lysis buffer were homogenized using a FastPrep-24 ${ }^{\mathrm{TM}}$ Classic homogenizer (MP Biomedicals) after adding sodium dodecyl sulfate $(2 \%)$. The quantity and integrity of extracted DNA were analyzed using a NanoDrop 1000 spectrophotometer (Thermo Fisher Scientific, Waltham, MA, USA). Extracted fecal DNA was aliquoted and stored at $-70{ }^{\circ} \mathrm{C}$ until being used for library preparation and qPCR analysis.

\subsection{Primer Design and PCR Amplification of Prey Items}

Metabarcoding analyses were conducted with two universal primers to amplify trace amounts of diet from fecal DNA. A eukaryotic-specific universal primer set targeting the V9 region of 18S rRNA (18Sv9) was adopted for the overall prey composition, with an amplicon size of approximately 115-140 bp [20]. For the fish taxa, we initially tested the MiFish primer set, which has been widely used for environmental DNA (eDNA) metabarcoding analysis of fish taxa [21]. However, it showed a high degree of cross-reactivity to host DNA, presenting little prey DNA in the metabarcoding results (data not shown). Thus, another fish-specific primer set targeting the same region was designed by multiple alignment of 
the currently reported $12 S$ region of 122 Antarctic fish and Adélie penguins using Geneious software [22]. The barcode size amplified by the primer set, named "miniFish", was approximately $91 \mathrm{bp}$ (Table 2).

Table 2. Primers used in qPCR and NGS analysis of fecal DNA of Adélie penguins (Pygoscelis adeliae).

\begin{tabular}{|c|c|c|c|}
\hline Name & Sequence $\left(5^{\prime}\right.$ to $\left.3^{\prime}\right)$ & $\begin{array}{l}\text { Size } \\
\text { (bp) }\end{array}$ & Description \\
\hline Eus-F & СССТТССТТАAСТСТСТTATTAGGAAGA & \multirow{2}{*}{154} & qPCR for \\
\hline Eus-R & TGAAGAAGCACCGGCAATATGAAGC & & (This study) \\
\hline Euc-F & GAAGTCTAATTGGGGACGACCAG & \multirow{2}{*}{207} & qPCR for \\
\hline Euc-R & CTAGTAAAAGAGTTAAGGAAGGAGGC & & $\begin{array}{l}\text { E. crystallorophias } \\
\text { (This study) }\end{array}$ \\
\hline miniFish-F & GTTATACGAGAGGCCCAAGTTG & \multirow{2}{*}{133} & \multirow{2}{*}{$\begin{array}{l}\text { qPCR for fish taxa } \\
\text { (This study) }\end{array}$} \\
\hline miniFish-R & TAAAGCCACTTTCGTGGTTG & & \\
\hline NGSmFish-F & $\begin{array}{c}\text { TCGTCGGCAGCGTCAGATGTGTATAAGAG } \\
\text { ACAGGTTATACGAGAGGCCCAAGTTG }\end{array}$ & \multirow{2}{*}{200} & \multirow{2}{*}{$\begin{array}{l}\text { NGS for fish taxa } \\
\text { (This study) }\end{array}$} \\
\hline NGSmFish-R & $\begin{array}{c}\text { GTCTCGTGGGCTCGGAGATGTGTATAAGAG } \\
\text { ACAGTAAAGCCACTTTCGTGGTTG }\end{array}$ & & \\
\hline NGS18Sv9-F & $\begin{array}{c}\text { TCGTCGGCAGCGTCAGATGTGTATAAGAG } \\
\text { ACAGTTGTACACACCGCCCGTCGC }\end{array}$ & \multirow{2}{*}{230} & \multirow{2}{*}{$\begin{array}{l}\text { NGS for } \\
\text { eukaryotes [20] }\end{array}$} \\
\hline NGS18Sv9-R & $\begin{array}{l}\text { GTCTCGTGGGCTCGGAGATGTGTATAAGA } \\
\text { GACAGCCTTCYGCAGGTTCACCTAC }\end{array}$ & & \\
\hline
\end{tabular}

\subsection{Library Construction and NGS}

Two PCR steps were used to construct the NGS library; 18Sv9 and miniFish primers were used for eukaryotic and fish taxa, respectively (Table 2). The first PCR for the MiSeq platform was conducted with primers overhanging the linker sequence for the Nextera XT Index Kit (Illumina, San Diego, CA, USA). The first PCR mixtures $(20 \mu \mathrm{L})$ contained $1 \mu \mathrm{L}$ of a template (5-20 ng/ $\mu \mathrm{L}$ conc.), $1 \mu \mathrm{L} \mathrm{F/R}$ primer (10 pmol) each, $2 \mu \mathrm{L}$ dNTPs (each $2.5 \mathrm{mM})$, $2 \mu \mathrm{L} 10 \times$ Ex Taq Buffer, $0.2 \mu \mathrm{L}$ ExTaq HS DNA polymerase (Takara, Shiga, Japan), and DNase/RNase free water. PCR amplification was performed under the following cycling conditions: initial denaturation at $94{ }^{\circ} \mathrm{C}$ for $3 \mathrm{~min}$, followed by 20 cycles of $94{ }^{\circ} \mathrm{C}$ for $30 \mathrm{~s}$, then $60{ }^{\circ} \mathrm{C}$ for $30 \mathrm{~s}$ for $18 \mathrm{~Sv} 9$ primers or $55^{\circ} \mathrm{C}$ for $30 \mathrm{~s}$ for miniFish, $72{ }^{\circ} \mathrm{C}$ for $30 \mathrm{~s}$, with a final extension of $3 \mathrm{~min}$ at $72{ }^{\circ} \mathrm{C}$. The amplified PCR products were stained with loading STAR (Dynebio, Republic of Korea) after 1\% agarose gel electrophoresis. The amplicons of the expected size on the gel (approximately $230 \mathrm{bp}$ for 18Sv9 and $200 \mathrm{bp}$ for miniFish) were purified using an AccuPrep Gel Purification Kit (Bioneer, Daejeon, Republic of Korea) for the second PCR.

The second PCR amplification was conducted using a Nextera XT Index Kit (Illumina, San Diego, CA, USA) following the manufacturer's instructions. The constructed libraries were identified by 1.5\% agarose gel electrophoresis (approximately 270-300 bp) and further purified using the AccuPrep Gel Purification Kit (Bioneer, Daejeon, Republic of Korea). The integrity and quantity of the constructed libraries were measured using a Quantus fluorometer (Promega, Madison, WI, USA) and a BioAnalyzer 2100 (Agilent Technologies, Palo Alto, CA, USA). The indexed libraries were sequenced on the Illumina MiSeq platform using a MiSeq Reagent v3 600-cycle kit (Illumina, San Diego, CA, USA).

\subsection{Bioinformatics Analysis}

After adapter/index sequences were trimmed from the raw MiSeq reads and reads with a QV below 20, fewer than 100 nucleotides were discarded using CLC Genomics Workbench v.8.0 (CLC Bio, Cambridge, MA, USA). The trimmed raw reads were further merged using mothur (v.1.43.0) software [23]. The merged reads were screened with 
criteria of $7 \mathrm{bp}$ overlap, zero mismatches, trimmed primer sequences, and expected size (115-140 bp for eukaryotes and $91 \mathrm{bp}$ for fish taxa). The merged reads were clustered into operational taxonomic units (OTUs) at $99.6 \%$ of sequence identity. OTU clustering and the removal of chimeric sequences were conducted using UCHIME [24]. The OTUs were annotated with BLASTN (v.2.7.1) against the NCBI NT sequence database. Species names were assigned for each OTU with a sequence identity higher than or equal to $99 \%$. Those whose identity ranged from 90 to $99 \%$ in the 18 Sv 9 metabarcoding and from 95 to $99 \%$ in the miniFish metabarcoding received genus names. OTUs with lower identities were considered "unknown". Nonmetric multidimensional scaling (NMDS) analysis was performed based on the Bray-Curtis distance of phylum and genus proportions from the 18Sv9 and miniFish metabarcoding, respectively.

\section{6. qPCR Analysis}

qPCR was performed using 3 designed specific primers to estimate the abundance of fish taxa and 2 krill species (E. superba and E. crystallorophias) in the fecal DNA sample sets (Table 2). A standard curve was constructed for each primer set using the serially diluted plasmid harboring each target sequence, as described in a previous study [25]. qPCR was conducted using a Mic qPCR cycler system (BioMolecular Systems, Upper Coomera, Australia). The qPCR mixture in a $20 \mu \mathrm{L}$ volume included $2 \mu \mathrm{L}$ genomic DNA, $1 \mu \mathrm{L}$ each of forward and reverse primer (10 pmol), $6 \mu \mathrm{L}$ DNase/RNase free water, and $10 \mu \mathrm{L} 2 \times$ Luna Universal qPCR master mix (New England Biolabs, USA). PCR conditions for fish taxa included initial denaturation at $95^{\circ} \mathrm{C}$ for $5 \mathrm{~min}$, followed by 40 cycles at $95^{\circ} \mathrm{C}$ for $5 \mathrm{~s}, 55^{\circ} \mathrm{C}$, for $20 \mathrm{~s}$, and $72{ }^{\circ} \mathrm{C}$ for $20 \mathrm{~s}$, and a final extension at $72^{\circ} \mathrm{C}$ for $3 \mathrm{~min}$, while those for the 2 krill consisted of initial denaturation at $94^{\circ} \mathrm{C}$ for $5 \mathrm{~min}$, followed by 40 cycles at $94{ }^{\circ} \mathrm{C}$ for $30 \mathrm{~s}$, $64.9^{\circ} \mathrm{C}$ for $15 \mathrm{~s}$, and $72{ }^{\circ} \mathrm{C}$ for $15 \mathrm{~s}$, and a final extension at $72{ }^{\circ} \mathrm{C}$ for $5 \mathrm{~min}$. A melting curve was generated after the final extension step of each assay in a 65 to $95^{\circ} \mathrm{C}$ melting gradient at a rate of $0.3^{\circ} \mathrm{C} / \mathrm{s}$. The fidelity of each qPCR assay was verified with corresponding fish and krill genomic DNA as positive control and water as negative control. Additionally, the specificity of the 2 krill-specific primer sets was confirmed by negative amplification for nontarget krill species, whereas the specificity of the miniFish primers was established using metabarcoding analysis. The calculation of copy numbers was based on $\mathrm{Ct}$ values of samples in each standard curve. Each copy number was normalized by dividing the $18 \mathrm{~S}$ rRNA gene copy number as an endogenous control.

\section{Results}

\subsection{Fecal DNA Metabarcoding of Pygoscelis Adeliae in the Ross Sea Region Using 18 Sv9 Universal Primers}

In total, 143 fecal DNA from seven sample sites were prepared during the surveys from December 2017 to January 2020. Metabarcoding analysis was conducted with 14 pooled samples from different habitats and years (Table 1). To know the overall diet composition of Adélie penguins, the first metabarcoding analysis was performed using the 18Sv9 universal primer set. On average, 204,657 raw reads were generated from each pooled sample based on MiSeq sequencing. The lowest and highest raw read numbers were obtained at II in $2018(65,911)$ and $\mathrm{MC}$ in $2017(413,458)$ (Table 3). After trimming, more than $80 \%$ of the raw reads for each site were used for further analysis as the reliable "merged reads," supporting the quality of NGS reads (Table 3). Despite their specificity for eukaryotic taxa, the merged reads generated by the $18 \mathrm{~Sv} 9$ universal primer set still presented a high number of bacterial taxa, whose proportion in pooled samples ranged from 24.72 to $68.17 \%$. In addition to bacterial sequences, the ratio of penguin DNA was high, ranging from 17.54 to $50.07 \%$. After eliminating the bacterial and penguin DNA, only tiny proportions $(0.07-31.15 \%)$ were obtained as putative prey items of Adélie penguins (Table 3). We failed to identify the species level, mainly because of low sequence variability in the $18 \mathrm{~Sv} 9$ marker. Hence, prey items in each pooled sample were further classified into five phyla: Annelida, Arthropoda, Chordata, Mollusca, and Unknown (Figure 2). Among the five phyla, arthropods were most 
abundant, making up $61.33 \%$ on average, followed by unknown $(26.20 \%)$ and chordates (11.66\%). Two phyla, Annelida (0.39\%) and Mollusca (0.43\%), were negligible (Figure 2).

Table 3. Reads of fecal DNAs generated using 18Sv9 universal primer set.

\begin{tabular}{|c|c|c|c|c|c|c|c|c|c|c|}
\hline Year & Site & $\begin{array}{c}\text { Raw } \\
\text { Reads }\end{array}$ & Merged & Trimmed (\%) & $\begin{array}{l}\text { Total } \\
\text { OTUs }\end{array}$ & $\begin{array}{l}\text { Bacterial } \\
\text { OTUs (\%) }\end{array}$ & $\begin{array}{l}\text { Penguin } \\
\text { OTUs (\%) }\end{array}$ & $\begin{array}{c}\text { Other } \\
\text { OTUs (\%) }\end{array}$ & $\begin{array}{l}\text { Unknown } \\
\text { OTUs (\%) }\end{array}$ & $\begin{array}{c}\text { Prey OTUs } \\
(\%)\end{array}$ \\
\hline \multirow[t]{3}{*}{2017} & $\mathrm{CH}$ & 206,799 & 191,923 & $172,527(83.42)$ & 1908 & $906(47.48)$ & 761 (39.88) & $25(1.31)$ & $212(11.11)$ & $4(0.20)$ \\
\hline & $\mathrm{MC}$ & 413,457 & 366,886 & $344,960(83.43)$ & 2521 & 819 (32.48) & 771 (30.58) & $316(12.53)$ & $172(6.82)$ & $443(17.57)$ \\
\hline & II & 287,458 & 262,918 & 238,667 (83.02) & 2863 & $1472(51.41)$ & $640(22.35)$ & $74(2.58)$ & 388 (13.55) & 289 (10.09) \\
\hline \multirow[t]{6}{*}{2018} & CA & 99,042 & 95,425 & $87,731(88.57)$ & 1351 & $334(24.72)$ & $567(41.96)$ & $26(1.92)$ & $57(4.21)$ & 367 (27.16) \\
\hline & DY & 136,739 & 131,310 & $122,607(89.66)$ & 2234 & $1523(68.17)$ & 392 (17.54) & $25(1.11)$ & $289(12.93)$ & $5(0.22)$ \\
\hline & $\mathrm{CH}$ & 112,246 & 108,092 & $100,432(89.47)$ & 1544 & $440(28.49)$ & 511 (33.09) & $23(1.48)$ & $89(5.76)$ & $481(31.15)$ \\
\hline & $\mathrm{CW}$ & 88,125 & 84,967 & $78,241(88.78)$ & 1252 & $486(38.81)$ & $652(52.07)$ & $20(1.59)$ & $93(7.42)$ & $1(0.07)$ \\
\hline & $\mathrm{EP}$ & 80,022 & 77,651 & $71,633(89.51)$ & 1283 & $670(52.22)$ & $367(28.60)$ & $36(2.80)$ & 159 (12.39) & $51(3.97)$ \\
\hline & II & 65,911 & 64,148 & $58,519(88.78)$ & 1160 & 733 (63.18) & $327(28.18)$ & $9(0.77)$ & $50(4.31)$ & $41(3.53)$ \\
\hline \multirow{5}{*}{2019} & CA & 329,166 & 295,489 & $263,738(80.12)$ & 3647 & $1732(47.49)$ & $958(26.26)$ & $21(0.57)$ & 881 (24.15) & $55(1.50)$ \\
\hline & $\mathrm{CH}$ & 221,449 & 206,082 & $186,421(84.18)$ & 2063 & $647(31.36)$ & 498 (24.13) & $22(1.06)$ & 829 (40.18) & $67(3.24)$ \\
\hline & $\mathrm{MC}$ & 217,619 & 202,090 & 177,117 (81.38) & 1994 & $566(28.38)$ & $564(28.28)$ & $144(7.22)$ & $484(24.27)$ & $236(11.83)$ \\
\hline & $\mathrm{EP}$ & 256,131 & 236,177 & 212,579 (82.99) & 2666 & $1513(56.75)$ & $615(23.06)$ & $233(8.73)$ & $261(9.78)$ & $44(1.65)$ \\
\hline & II & 351,038 & 319,669 & $294,189(83.80)$ & 3743 & $2323(62.04)$ & 771 (20.59) & $38(1.01)$ & $564(15.06)$ & $48(1.28)$ \\
\hline
\end{tabular}

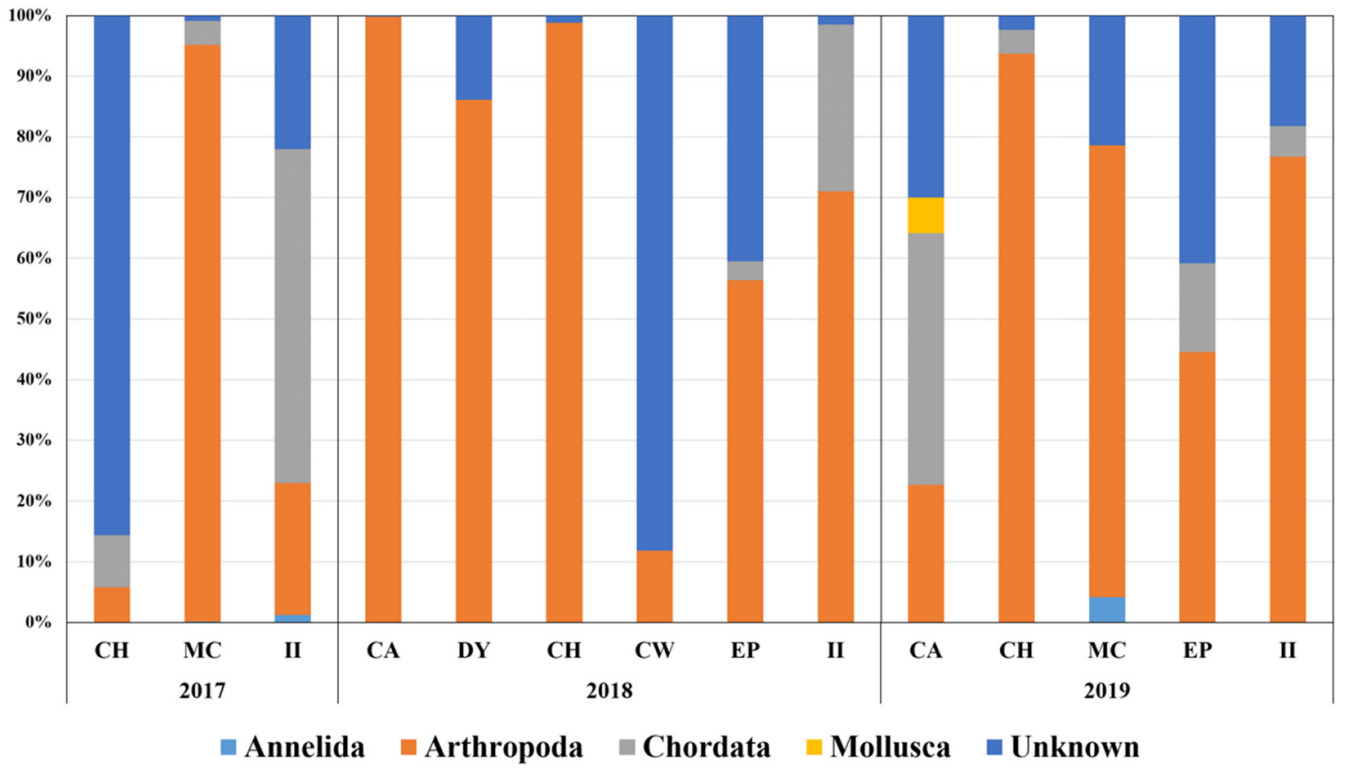

Figure 2. Metabarcoding of fecal DNA using 18Sv9 universal primer set. Graph displays proportions of phyla of prey items at different sites by year.

The arthropod OTUs belonged to either E. superba or E. crystallorophias, the average proportion of which among arthropod OTUs was $75.64 \%$. E. crystallorophias (49.88\%) was approximately two-fold higher than E. superba (25.14\%; Figure 2). The copepod OTUs placed second, with an average proportion in arthropod OTUs of $16.92 \%$. Among seven copepod genera, Calanus (7.78\%) was the most abundant, followed by Metridia (4.60\%) and Paraeuchaeta (1.90\%) (Figure 2). All OTUs in the phylum Chordata showed the highest identity to notothenioid fish, which is the most abundant fish taxon in the Southern Sea. Only two OTUs in Annelida have identified either Lumbrineris sp. or Tomopteris sp., whose average proportion was only $0.40 \%$ among the five taxa. One OTU in Mollusca showed the highest identity to Limacina helicina, a tiny swimming planktonic sea snail, which was identified only one time at CA in 2019. Finally, an unknown OTU showed the highest identity to Eimeria furonis, suggesting putative gastrointestinal helminths. Although Parorchites zederi and the nematode Stegophorus macronectes are among the parasites commonly found 
in penguins in Antarctica [26], we failed to identify the exact species, mainly because of the lack of reference sequences in the database.

Nonmetric multidimensional scaling (NMDS) analysis was conducted to compare community structures obtained by metabarcoding (Figure 3). Three clusters were observed via NMDS in the 18Sv9 metabarcoding analysis (Figure 3A). The first group (CW in 2018 and $\mathrm{CH}$ in 2017) was characterized by a high number of unknown parasites, mainly for those starved. The second group (CA in 2019 and II in 2017) showed a high number of Chordata taxa, mostly fish, whereas the others (group 3) exhibited an arthropod-dominant group, most of them belonging to krill. These data support the suggestion that krill are major prey of Adélie penguins in the Ross Sea, with a few exceptional cases.

(A)

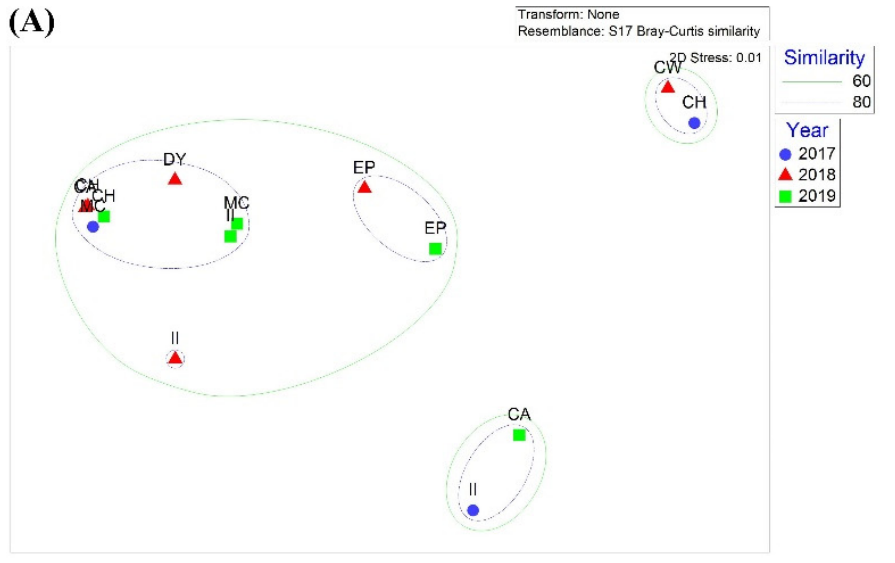

(B)

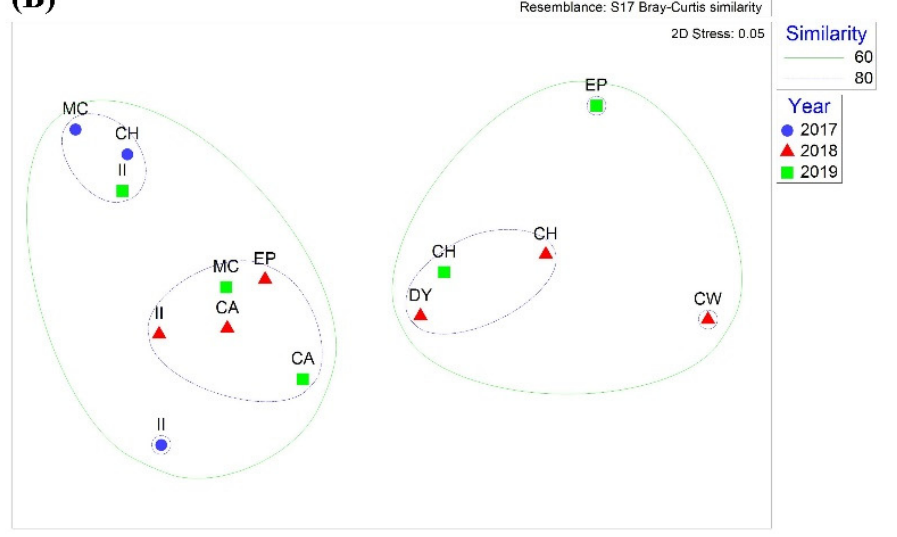

Figure 3. Nonmetric multidimensional scaling (NMDS) plot of (A) eukaryotic communities using 18Sv9 metabarcoding and (B) fish communities using miniFish metabarcoding in different years. Solid lines indicate $60 \%$ and $80 \%$ similarity.

\subsection{Fecal DNA Metabarcoding of Pygoscelis Adeliae in the Ross Sea Region Using miniFish Primers}

Piscine prey items of $P$. adeliae were analyzed using the miniFish primer set (Figure 4). Approximately 1.3 million to 6.1 million raw reads were generated at each site. After trimming, the average proportion of qualified merged reads was $45.93 \%$, ranging from 3.22 to $76.97 \%$ (Table 4). Interestingly, extremely low numbers of qualified merged reads were obtained at CA in $2018(3.22 \%)$ and 2019 (8.11\%). The proportion of non-fish reads ranged from 4.10 to $15.73 \%$, indicating high specificity for piscine taxa.

Five families (Nototheniidae, Channichthyidae, Artedidraconidae, Bathydraconidae, and Harpagiferidae) covering 11 genera (Chaenocephalus, Chaenodraco, Chionobathyscus, Chionodraco, Cryodraco, Gymnodraco, Harpagifer, Pagothenia, Pleuragramma, Pogonophryne, and Trematomus) were detected as piscine prey of Adélie penguins via miniFish metabarcoding (Table 5). Of 22 haplotypes, 12 showed $100 \%$ sequence identity, indicating a high number of reference sequences for fish species in the Ross Sea. However, species names were unable to be assigned to three haplotypes from Trematomus, Chinodraco, and Pogonophryne because of the low variability to distinguish the relative species in each genus (Table 5). Among the 11 genera, the Antarctic silverfish, $P$. antarctica, was the most abundant, accounting for $56.50 \%$ of total piscine reads, followed by Pagothenia borchgrevinki $(18.20 \%)$, Chionodraco spp. $(9.61 \%)$, and Trematomus spp. (5.15\%).

The NMDS result showed two clusters but failed to identify any patterns by years and habitats (Figure 3B). The NMDS analysis showed that two clusters were determined by the proportions of the two main fish species. The first cluster included the nine sites where P. antarctica was the most abundant. At the same time, P. borchgrevinki was equivalent to or higher than P. antarctica at the other five sites (CH, DY, and CW in 2018 and $\mathrm{CH}$ and EP in 2019), indicating no spatiotemporal pattern (Figure 3B). 


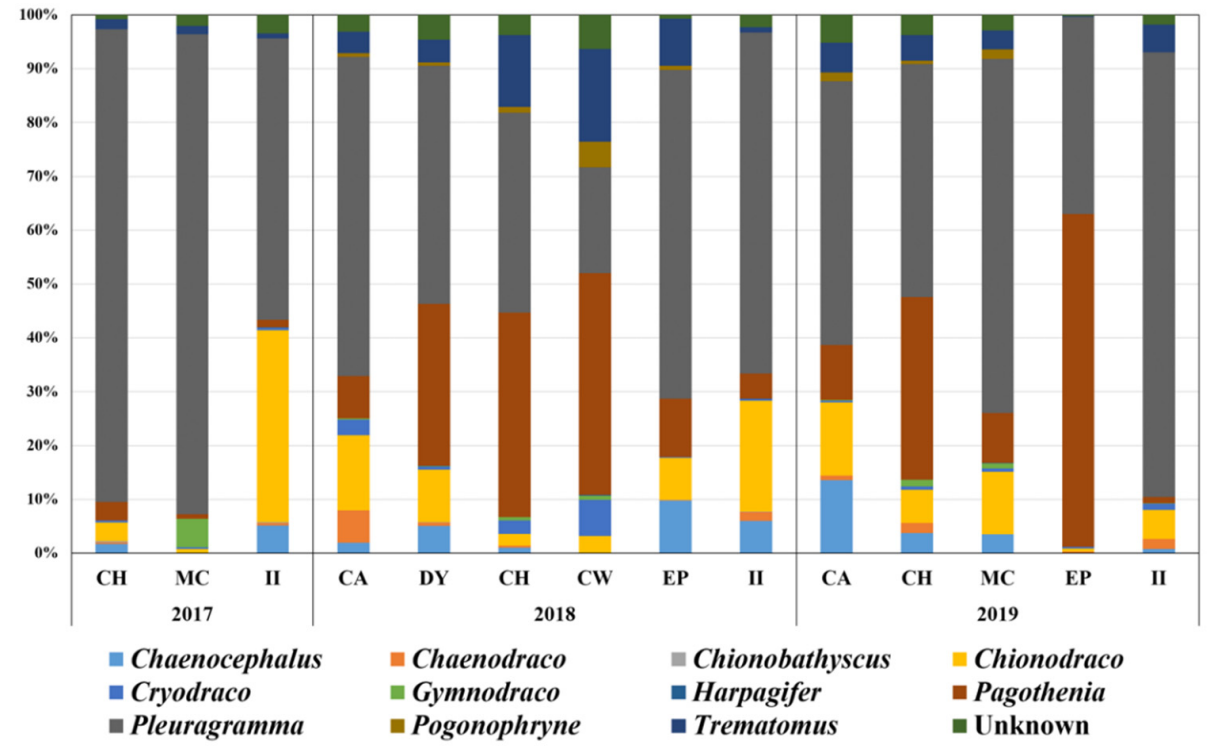

Figure 4. Prey items identified using miniFish metabarcoding. Graph displays proportions of prey items at the genus level at different sites by year.

Table 4. Metabarcoding reads of fecal DNAs generated using miniFish primer set.

\begin{tabular}{cccccccc}
\hline \multirow{2}{*}{ Year } & Site & Raw Reads & Merged & Trimmed (\%) & Total OTUs & $\begin{array}{c}\text { Nonfish OTUs } \\
\text { (\%) }\end{array}$ & $\begin{array}{c}\text { Fish OTUs } \\
\text { (\%) }\end{array}$ \\
\hline \multirow{2}{*}{2017} & CH & 466,869 & 417,192 & $89,933(19.26)$ & 1539 & $90(5.84)$ & $1449(94.15)$ \\
& MC & 430,858 & 390,434 & $295,728(68.63)$ & 3223 & $308(9.55)$ & $2915(90.44)$ \\
& II & 411,949 & 375,381 & $299,065(72.59)$ & 6793 & $1123(16.53)$ & $5670(83.46)$ \\
2018 & CA & 139,704 & 131,090 & $4,507(3.22)$ & 328 & $33(10.06)$ & $295(89.93)$ \\
& DY & 404,610 & 366,116 & $145,151(35.87)$ & 2759 & $301(10.90)$ & $2458(89.09)$ \\
& CH & 486,449 & 432,846 & $67,403(13.85)$ & 1780 & $213(11.96)$ & $1567(88.03)$ \\
& CW & 453,872 & 409,481 & $274,322(60.44)$ & 4939 & $777(15.73)$ & $4162(84.26)$ \\
& EP & 383,592 & 350,968 & $258,227(67.31)$ & 5075 & $417(8.21)$ & $4658(91.78)$ \\
& II & 613,755 & 540,098 & $397,584(64.77)$ & 7025 & $884(12.58)$ & $6141(87.41)$ \\
& CA & 366,387 & 332,391 & $29,732(8.11)$ & 1136 & $113(9.94)$ & $1023(90.05)$ \\
& CH & 546,858 & 484,040 & $203,386(37.19)$ & 3943 & $427(10.82)$ & $3516(89.17)$ \\
& MC & 535,567 & 475,415 & $261,071(48.74)$ & 5089 & $621(12.20)$ & $4468(87.79)$ \\
& EP & 355,283 & 327,315 & $273,474(76.97)$ & 2438 & $100(4.10)$ & $2338(95.89)$ \\
& II & 418,457 & 381,563 & $276,689(66.12)$ & 4121 & $450(10.91)$ & $3671(89.08)$ \\
\hline
\end{tabular}

Table 5. Fish species determined using miniFish metabarcoding in Ross Sea.

\begin{tabular}{|c|c|c|c|c|}
\hline Family & Species & Accession No. & Identity (\%) & Query Cover \\
\hline \multirow[t]{5}{*}{ Nototheniidae } & $\begin{array}{l}\text { Trematomus } \\
\text { loennbergii/lepidorhinus * }\end{array}$ & NC048965/MN864240 & $100 / 100$ & 100 \\
\hline & Pagothenia borchgrevinki & KU951144, KX025131 & 100 & 100 \\
\hline & Pleuragramma antarctica & JF933905 & 100 & 100 \\
\hline & Trematomus bernacchii & MN841276 & 100 & 100 \\
\hline & Trematomus pennellii & MK007073 & 100 & 100 \\
\hline \multirow[t]{5}{*}{ Channichthyidae } & $\begin{array}{l}\text { Chionodraco } \\
\text { hamatus/rastrospinosus * }\end{array}$ & $\begin{array}{l}\text { KT921282/ } \\
\text { NC039543 }\end{array}$ & $100 / 100$ & 100 \\
\hline & Chaenocephalus aceratus & JF933907 & 100 & 100 \\
\hline & Chaenodraco wilsoni & NC039158 & 100 & 100 \\
\hline & Chionodraco myersi & DQ526430 & 100 & 100 \\
\hline & Cryodraco antarcticus & NC045285 & 100 & 100 \\
\hline Artedidraconidae & $\begin{array}{l}\text { Pogonophryne } \\
\text { albipinna/scotti * }\end{array}$ & NC046024/LC069700 & $100 / 100$ & 100 \\
\hline Bathydraconidae & Gymnodraco acuticeps & U90413 & 100 & 100 \\
\hline
\end{tabular}

${ }^{*}$ Haplotypes with multiple species identities. 


\section{3. qPCR Analysis of Main Prey Items}

On the basis of the metabarcoding analysis of fecal DNA using two primer sets, two krill species (E. superba and E. crystallorophias) and notothenioid fish, especially $P$. antarctica and $P$. borchgrevinki, were identified among the most abundant prey items of Adélie penguins (Figure 4). To conduct a more accurate quantitative analysis of those main prey items, qPCR was adopted for individual samples of fecal DNA. Three primer sets, including two krill-specific primer sets (E. superba and E. crystallorophias) and one fish-specific (miniFish), were used for the quantitative analysis. The proportions of the main prey items showed clear geographic patterns. Higher proportions of E. superba and E. crystallorophias were respectively identified in the outbound and inbound habitats in the Ross Sea (Figure 5 and Table 6). In fact, the proportions of E. crystallorophias showed a clear opposite pattern to those of E. superba, whose highest proportions were identified in the most inbound habitats, EP and II. The proportion of E. superba at those two habitats was less than 1\% (Figure 5). By contrast, the proportion of E. superba was highest in the most outbound habitats, including CA and DY. The proportion of piscine diets showed a similar pattern with E. crystallorophias, in which the two most inbound habitats, EP and II, showed their highest proportions, while those in CA and DY were lower than 10\% (Figure 5).

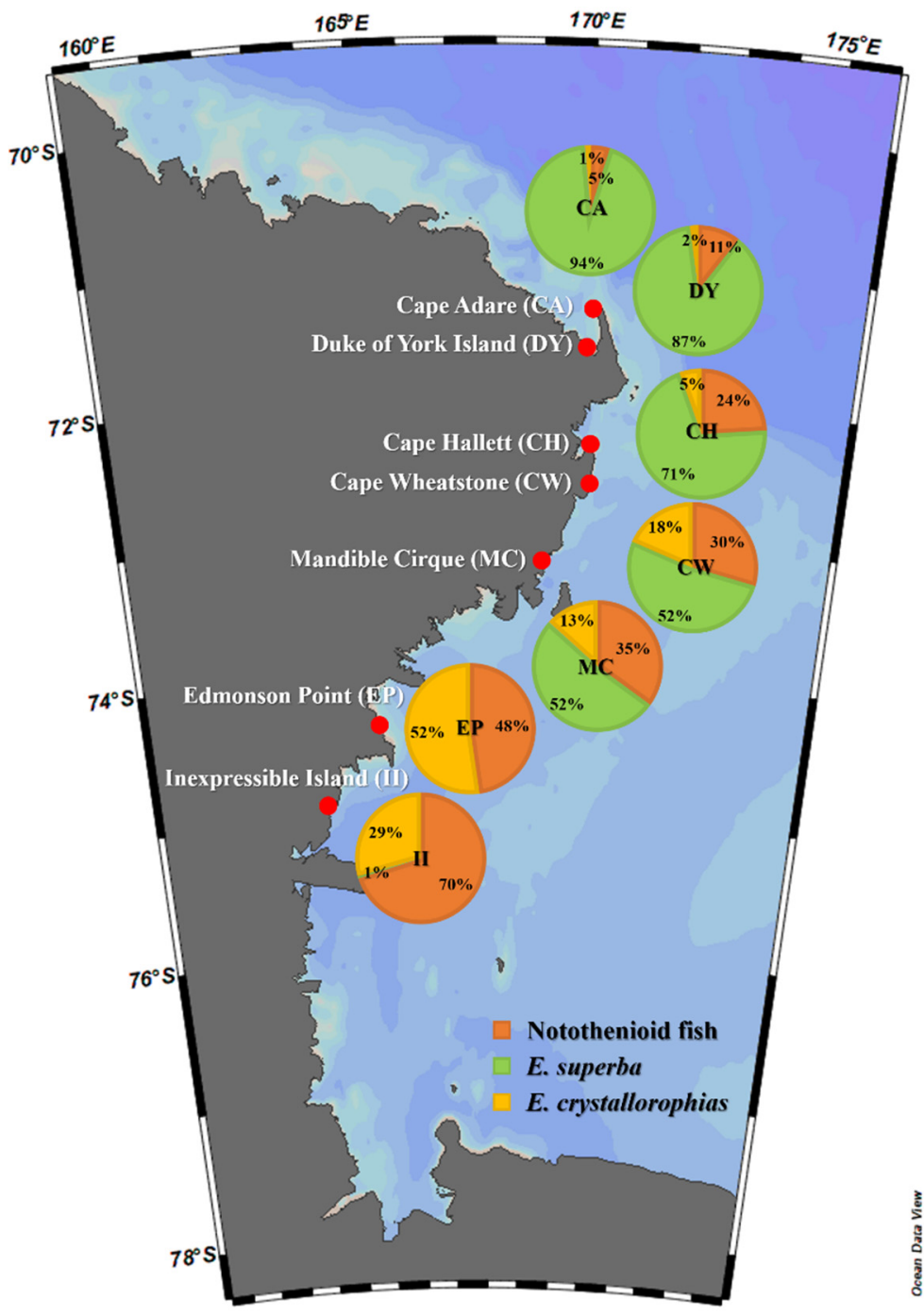

Figure 5. Geographic proportions of notothenioid fish, Euphausia superba, and Euphausia crystallorophias in fecal DNA of Adélie penguins (Pygoscelis adeliae) in the Ross Sea region. 
Table 6. Proportions of main prey items by quantitative analysis.

\begin{tabular}{cccccccc}
\hline & CA & DY & CH & CW & MC & EP & II \\
\hline Notothenioid fish (\%) & 4.84 & 10.57 & 24.09 & 29.57 & 35.04 & 47.68 & 70.11 \\
E. superba (\%) & 93.76 & 87.40 & 70.54 & 52.00 & 51.66 & 0.00 & 0.45 \\
E. crystallorophias (\%) & 1.40 & 2.03 & 5.37 & 18.43 & 13.30 & 52.31 & 29.44 \\
\hline
\end{tabular}

Annual proportional changes of the main prey items (Notothenioid fish, E. superba, and E. crystallorophias) were also analyzed at two sites ( $\mathrm{CH}$ and II), where all 3-year scat samples were collected in the Ross Sea (Figure 6). Proportions of the main prey were similar for 3 years at the outbound habitat (CA), among which E. superba was the largest, followed by notothenioid fish and E. crystallorophias. By contrast, their proportions were highly variable year to year in the inbound habitat (II). In 2017 and 2019, a higher proportion of fish prey was identified, while a predominant proportion of E. crystallorophias was found in 2018 (Figure 6). Even between 2017 and 2019, we were able to identify differences in krill composition. Compared to 2017, much higher proportions of E. superba and E. crystallorophias were found in 2019. However, E. crystallorophias was the main krill prey of Adélie penguins in the inbound habitat, II (Figure 6).

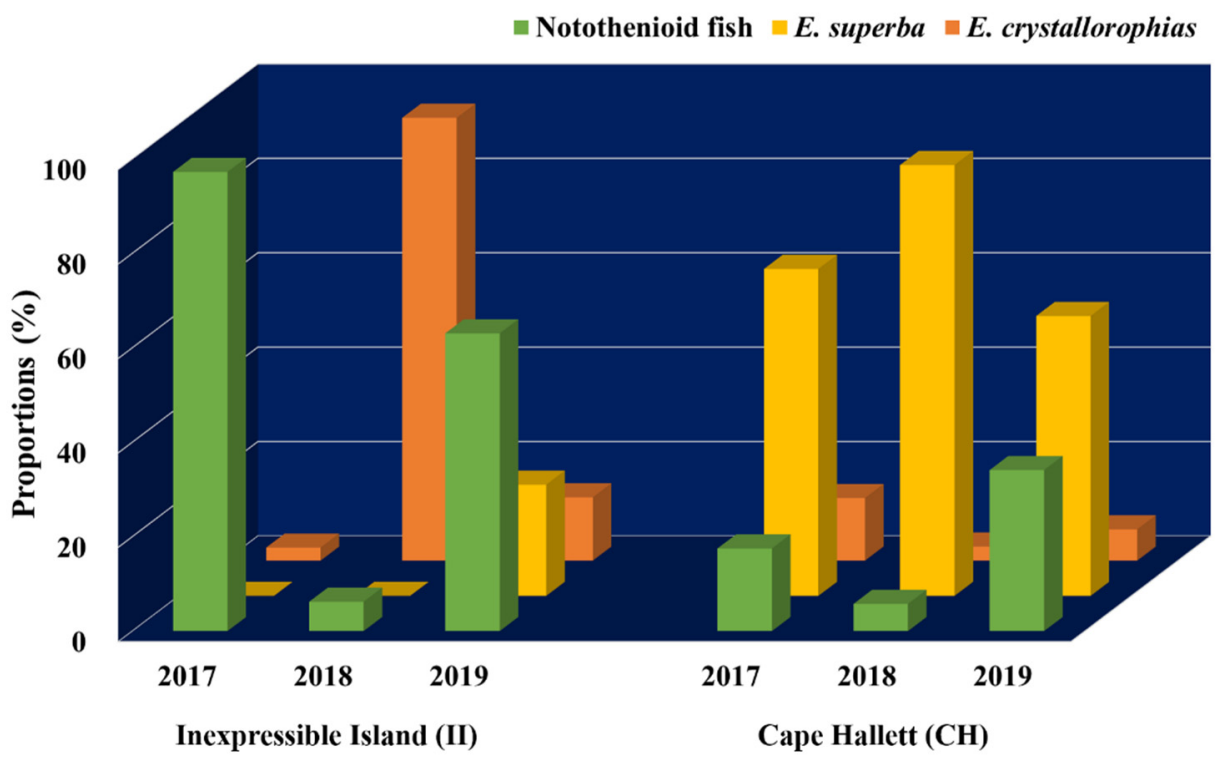

Figure 6. Proportions of main prey items (Notothenioid fish, Euphausia superba, and Euphausia crystallorophisa) in fecal DNA of Adélie penguins (Pygoscelis adeliae) at Inexpressible Island (II) and Cape Hallett $(\mathrm{CH})$ for three successive years.

\section{Discussion}

We analyzed the diets of Adélie penguins in the Ross Sea region by metabarcoding of fecal DNA with multiple markers (18Sv9 and miniFish). The barcode sizes amplified by the two primer sets were approximately $91-140 \mathrm{bp}$, which were much smaller than regular barcodes. The quality and quantity of dietary DNA remaining in the scat are often much lower compared to other environmental samples because of the vigorous digestion process [27]. Therefore, amplifying of short sequences, named "minibarcodes", is used for samples containing degraded DNA such as processed food, water, soil, or scat $[28,29]$. Although it is one of the most widely used methods [30-32], mitochondrial COI minibarcodes show a high degree of cross-reactivity with bacterial DNA presenting most of their sequences, which outnumbered the trace amounts of degraded dietary DNA. We alternatively applied the nuclear $18 \mathrm{~Sv} 9$ universal primer set, which was explicitly designed for eukaryotic taxa $[33,34]$. However, it also amplified a large amount of predator and bacterial DNA, accounting for up to $80 \%$ of total metabarcode reads (Table 3). Blocking 
primers are often used to suppress the host DNA in metabarcoding results $[35,36]$. We also tried them, but this attempt failed because they suppressed the DNA of penguins and dietary items (data not shown). Despite the short amplicon size and low sequence variability, metabarcoding analysis using the 18Sv9 primer set successfully showed the overall prey items of Adélie penguins in the Ross Sea at the phylum level, in which krill and notothenioid fish were the main prey items (Figure 2).

In addition to the diet study, 18Sv9 rRNA metabarcoding results of the penguins' fecal DNA provided additional information. For instance, diverse putative parasites were identified, including Platyhelminthes (Diphyllobothrium pacificum, Parorchites zederi, Parorchites sp., Spirometra erinaceieuropaei, and Zygobothrium sp.), Chaetognatha (Pseudosagitta sp.), Tardigrada (Acutuncus antarcticus), Nematoda (Contracaecum osculatum), and Apicomplexa (Eimeria sp.). Many of them are among the previously reported parasites of Adélie penguins. P. zederi is one of the common parasites in Adélie penguins [26], and D. pacificum is one of the most widely identified parasites among the animals inhabiting Antarctica [37]. Eimeria $\mathrm{sp}$. is also one of the three main Coccidian parasites (Apicomplexa) of penguins inhabiting Livingston Island and King George Island [38]. It is generally known that parasite composition is highly related to diet composition [39,40], and in particular, euphausiid species are known to be intermediate hosts for parasite species of Adélie penguins [26]. Further studies should be conducted to determine the relationship between diet composition and parasitic species, which may provide helpful information about their ecological implications in the Ross Sea. Moreover, parasite composition should be further monitored to estimate the health condition of Adélie penguins. Although Dibothriocephalus, Adenocephalus, and Diphyllobothrium are considered commensal parasites, the larva of some Spirometra can cause life-threatening diseases to host species [41]. Therefore, monitoring them with the use of molecular tools would be important not only in terms of their ecological implications but also for the sustainability of penguin colonies.

While the 18Sv9 primer set presented the overall prey items of Adélie penguins in the Ross Sea at the phylum level, its low sequence variability and short barcode size made it possible to analyze up to the species level. We obtained detailed information regarding the penguins' fish diet using a fish-specific universal primer, miniFish, targeting their mitochondrial $12 \mathrm{~S}$ region. The newly designed miniFish primer set showed a high degree of specificity for fish taxa (Notothenioidei) in the Southern Sea without amplifying either penguin or bacterial DNA (Table 4). Its amplicon size was also short (91 bp), which is suitable for amplifying fish sequences from highly degraded DNA samples isolated from scat, soil, or water. The amplified region lies within the MiFish marker, which is applicable to the established reference database [21]. Most of the haplotypes obtained by miniFish showed a high degree of sequence identity, assigning each species name and supporting a high number of reference sequences for fish species inhabiting the Ross Sea. However, because of its short amplicon size, some species in three genera, Chionodraco, Pogonophryne, and Trematomus, were indiscriminate using miniFish metabarcoding (Table 5). Those weaknesses can be compensated by comparative analysis of regional fish assemblage data obtained via eDNA metabarcoding using a more extended barcode primer set such as MiFish [21]. The newly designed miniFish primer would be a valuable tool for diet studies of piscivorous predators, such as penguins and seals in Antarctica.

miniFish metabarcoding showed that $P$. antarctica was the most abundant fish prey of Adélie penguins, making up $56.50 \%$ on average, followed by P. borchgrevinki (18.21\%), Chionodraco spp. (9.61\%), and Trematomus spp. (5.15\%), which is consistent with previous studies [42,43]. Since Adélie penguins are omnivorous predators, this result is reasonable, knowing that the Antarctic silverfish, $P$. antarctica, is the most abundant pelagic fish inhabiting the Ross Sea [44,45]. However, there are different reports regarding Adélie penguin diets in previous studies. Krill and P. borchgrevinki were found to be the main diet according to underwater camera surveillance [46]. Another study, based on isotope 13C and $15 \mathrm{~N}$ values, revealed that euphausiids are the main food source [47]. Those results may reflect regional characteristics, and metabarcoding analysis covered all cases. We 
identified a higher proportion of P. borchgrevinki than P. antarctica at several sites (Figure 4). In addition, compared with krill, an equal or higher number of fish taxa were shown at II in 2017 and 2018 (Figure 2). These proportions changed from year to year, and long-term metabarcoding analysis using a dual primer set would be one efficient strategy to determine the relationship between the proportions of prey and the environmental characteristics in the Ross Sea. Although P. antarctica was identified as the main fish prey of Adélie penguins, it is worth noting that 11 fish genera have been identified as prey items for these penguins in the Ross Sea, some of which are actually too large to be their prey (Figure 4). Furthermore, two genera, Chionodraco and Trematomus, made up approximately $15 \%$ of fish prey on average. Different from the two small pelagic fish prey, these two are known as demersal fish species. Terra Nova Bay, a highly productive area in the Ross Sea, is an important spawning and nursery ground for several fish species [48]. Thus, it would also be worth investigating the relationship between the reproduction of notothenioids and the dynamics of Adélie penguins.

While Adélie penguins' main diet was found to be krill and notothenioid fish, which is consistent with previous studies [6,15], neither hydrozoans nor cephalopods were identified from fecal DNA in this study (Figure 2 and Table 3). Recent studies showed that hydrozoans have increasingly grown as penguin prey, which is presumably because of climate change [6,15]. Cephalopod Psychroteuthis glacialis was also considered to be among the prey items of Adélie penguins [49]. However, these differences may come from the seasonal availability of non-fish taxa in some habitats, especially those located inbound of the Ross Sea. In previous studies, except for fish taxa, a high degree of seasonal changes in the penguins' diet was shown, which was presumably due to food availability by periodic changes in ice-covered regions along the inner coastal part of the Ross Sea such as polynyas [49,50]. Subsequently, more frequent and long-term surveys of Adélie penguins in the Ross Sea are required in order to understand the relationship between environmental changes and food availability in the region, and a long-term molecular survey of scat samples would be one of the most cost-effective strategies.

According to previous research, krill was found to be the most important prey of Adélie penguins in the Ross Sea. One of the most interesting findings by molecular analysis was a clear geographic difference of krill prey within the Ross Sea [51,52]. Higher proportions of E. superba were identified in the more outbound habitats, while the proportion of E. crystallorophias increased in the more inbound habitats (Figure 5). Differences in the abundance of two krill, E. superba and E. crystallorophias, are due to their availability in the Ross Sea. E. superba is considered a pelagic species in offshore areas, whereas E. crystallorophias is limited to inshore waters under ice [53]. Therefore, outbound habitats such as CA and DY would be favorable for E. superba, while the coastal waters near two inbound habitats, EP and II, may provide favorable conditions for E. crystallorophias rather than E. superba. We also identified that the prey of Adélie penguins inhabiting outbound habitats showed a rather stable pattern; the main prey was E. superba, with small amounts of fish species (Figure 6). By contrast, those in inbound habitats of the Ross Sea face a high degree of variation in their prey according to environmental changes. One of the most important environmental changes is the dynamics of the ice pack along the Ross Sea. Since they prefer being underneath the ice pack, changes in the availability of E. crystallorophias or fish may be related to polynya. Previous studies showed that the population of Adélie penguins is directly linked to sea ice [54] and temperature fluctuations [55]. This ecological indicator's productivity has been linked to Antarctic krill [56], which is also sea ice-bound $[57,58]$. This could help researchers better understand the population dynamics of Adélie penguins, especially among the inbound habitats in the Ross Sea. Collectively, we established a pipeline to analyze the diets of Adélie penguins from scat samples in the Ross Sea using molecular techniques. We were able to obtain detailed information on the prey species of Adélie penguins. We also found that the penguins' diets were highly affected by the geographic characteristics of the Ross Sea. Frequent and long-term surveys using this methodology would provide detailed information regarding the feeding ecology of 
Adélie penguins inhabiting the Ross Sea Region Marine Protected Area, which would be of practical use for their scientific conservation and management.

\section{Conclusions}

The diets of Adélie penguins (P. adeliae) were analyzed using fecal DNA with NGS and qPCR techniques. The combination of molecular tools used in this study successfully elucidated that two krill species and notothenioid fish are the penguins' main diet species. However, diet compositions were highly variable according to the environmental conditions and geographic food availability. These data will help researchers expand our knowledge of the role of Adélie penguins in the ecosystem of the Ross Sea. Further studies should be conducted to understand the relationship between meteorological phenomena such as the occurrence of polynya and the diets of Adélie penguins in the Ross Sea.

Author Contributions: Conceptualization, J.-H.K. and H.-W.K.; methodology, N.T., J.-H.L., S.-R.L., H.P., J.-H.K., and H.-W.K.; data curation, N.T. and J.-H.L.; writing-original draft preparation, J.-H.L. and N.T.; writing-review and editing, N.T., J.-H.L., J.-U.K., J.-H.K., and H.-W.K.; visualization, J.-H.L. and N.T.; supervision, J.-H.K. and H.-W.K.; project administration, J.-H.K.; funding acquisition, J.-H.K. and H.-W.K. All authors have read and agreed to the published version of the manuscript.

Funding: This research was supported by the Ecosystem Structure and Function of Marine Protected Area (MPA) in Antarctica project (PM21060), funded by the Ministry of Oceans and Fisheries (20170336), Korea, and partially supported by the Basic Science Research Program of the National Research Foundation of Korea (NRF) and the Ministry of Education (2021R1A6A1A03039211).

Institutional Review Board Statement: Not applicable.

Informed Consent Statement: Not applicable.

Data Availability Statement: The sequencing data in this study are registered with the NCBI database under BioProject ID PRJNA749147.

Acknowledgments: We thank Jin-Woo Jung, Woo-Sung Kim, and Junseo Go, who collected scat in the Ross Sea region.

Conflicts of Interest: The funders played no role in the study's design; collection, analysis, or interpretation of the data; the writing of the manuscript; or the decision to publish the results.

$\begin{array}{ll}\text { Abbreviations } \\ \text { qPCR } & \text { quantitative polymerase chain reaction } \\ \text { OTUs } & \text { operational taxonomic units } \\ \text { CA } & \text { Cape Adare } \\ \text { DY } & \text { Duke of York Island } \\ \text { CH } & \text { Cape Hallett } \\ \text { CW } & \text { Cape Wheatstone } \\ \text { MC } & \text { Mandible Cirque } \\ \text { EP } & \text { Edmonson Point } \\ \text { II } & \text { Inexpressible Island }\end{array}$

\section{References}

1. Ainley, D.; Russell, J.; Jenouvrier, S.; Woehler, E.; Lyver, P.O.B.; Fraser, W.R.; Kooyman, G.L. Antarctic penguin response to habitat change as Earth's troposphere reaches 2 C above preindustrial levels. Ecol. Monogr. 2010, 80, 49-66. [CrossRef]

2. Millar, C.D.; Subramanian, S.; Heupink, T.H.; Swaminathan, S.; Baroni, C.; Lambert, D.M. Adelie penguins and temperature changes in Antarctica: A long-term view. Integr. Zool. 2012, 7, 113-120. [CrossRef] [PubMed]

3. Wilson, R. An improved stomach pump for penquins and other seabirds. J. Field Ornithol. 1984, 55, $109-112$.

4. Watanabe, Y.Y.; Ito, K.; Kokubun, N.; Takahashi, A. Foraging behavior links sea ice to breeding success in Antarctic penguins. Sci. Adv. 2020, 6, eaba4828. [CrossRef]

5. Olmastroni, S.; Corsolini, S.; Pezzo, F.; Focardi, S.; Kerry, K. The first five years of the Italian-Australian joint programme on the Adélie Penguin: An overview. Ital. J. Zool. 2000, 67, 141-145. [CrossRef] 
6. Jarman, S.N.; McInnes, J.C.; Faux, C.; Polanowski, A.M.; Marthick, J.; Deagle, B.E.; Southwell, C.; Emmerson, L. Adélie penguin population diet monitoring by analysis of food DNA in scats. PLoS ONE 2013, 8, e82227. [CrossRef]

7. Johnson, S.R.; West, G.C. Fat content, fatty acid composition and estimates of energy metabolism of adélie penguins (Pygoscelis adeliae) during the early breeding season fast. Comp. Biochem. Physiol. Part B Comp. Biochem. 1973, 45, 709-719. [CrossRef]

8. Emslie, S.D.; Patterson, W.P. Abrupt recent shift in delta $13 \mathrm{C}$ and delta $15 \mathrm{~N}$ values in Adélie penguin eggshell in Antarctica. Proc. Natl. Acad. Sci. USA 2007, 104, 11666-11669. [CrossRef]

9. Lishman, G.S. The food and feeding ecology of Adélie penguins (Pygoscelis adeliae) and Chinstrap penguins (P. antarctica) at Signy Island, South Orkney Islands. J. Zool. 1985, 205, 245-263. [CrossRef]

10. Juáres, M.A.; Santos, M.; Mennucci, J.A.; Coria, N.R.; Mariano-Jelicich, R. Diet composition and foraging habitats of Adélie and gentoo penguins in three different stages of their annual cycle. Mar. Biol. 2016, 163, 105. [CrossRef]

11. Beng, K.C.; Corlett, R.T. Applications of environmental DNA (eDNA) in ecology and conservation: Opportunities, challenges and prospects. Biodivers. Conserv. 2020, 29, 2089-2121. [CrossRef]

12. Evans, N.T.; Shirey, P.D.; Wieringa, J.G.; Mahon, A.R.; Lamberti, G.A. Comparative cost and effort of fish distribution detection via environmental DNA analysis and electrofishing. Fisheries 2017, 42, 90-99. [CrossRef]

13. Taberlet, P.; Bonin, A.; Zinger, L.; Coissac, E. Environmental DNA: For Biodiversity Research and Monitoring; Oxford University Press: Oxford, UK, 2018.

14. Grzesiak, J.; Kaczyńska, A.; Gawor, J.; Żuchniewicz, K.; Aleksandrzak-Piekarczyk, T.; Gromadka, R.; Zdanowski, M.K. A smelly business: Microbiology of Adélie penguin guano (Point Thomas rookery, Antarctica). Sci. Total Environ. 2020, 714, 136714. [CrossRef] [PubMed]

15. McInnes, J.C.; Emmerson, L.; Southwell, C.; Faux, C.; Jarman, S.N. Simultaneous DNA-based diet analysis of breeding, nonbreeding and chick Adelie penguins. R. Soc. Open Sci. 2016, 3, 150443. [CrossRef] [PubMed]

16. Goldsworthy, B.; Young, M.J.; Seddon, P.J.; van Heezik, Y. Stomach flushing does not affect apparent adult survival, chick hatching, or fledging success in yellow-eyed penguins (Megadyptes antipodes). Biol. Conserv. 2016, 196, 115-123. [CrossRef]

17. Lyver, P.O.B.; Barron, M.; Barton, K.J.; Ainley, D.G.; Pollard, A.; Gordon, S.; McNeill, S.; Ballard, G.; Wilson, P.R. Trends in the breeding population of Adélie penguins in the Ross Sea, 1981-2012: A coincidence of climate and resource extraction effects. PLoS ONE 2014, 9, e91188. [CrossRef]

18. Lynch, H.; LaRue, M. First global census of the Adélie Penguin. Auk Ornithol. Adv. 2014, 131, 457-466. [CrossRef]

19. Beaulieu, M.; Thierry, A.-M.; Raclot, T.; Le Maho, Y.; Ropert-Coudert, Y.; Gachot-Neveu, H.; Ancel, A. Sex-specific parental strategies according to the sex of offspring in the Adélie penguin. Behav. Ecol. 2009, 20, 878-883. [CrossRef]

20. Tragin, M.; Zingone, A.; Vaulot, D. Comparison of coastal phytoplankton composition estimated from the V4 and V9 regions of the 18S rRNA gene with a focus on photosynthetic groups and especially Chlorophyta. Environ. Microbiol. 2018, 20, 506-520. [CrossRef]

21. Miya, M.; Sato, Y.; Fukunaga, T.; Sado, T.; Poulsen, J.Y.; Sato, K.; Minamoto, T.; Yamamoto, S.; Yamanaka, H.; Araki, H. MiFish, a set of universal PCR primers for metabarcoding environmental DNA from fishes: Detection of more than 230 subtropical marine species. R. Soc. Open Sci. 2015, 2, 150088. [CrossRef]

22. Kearse, M.; Moir, R.; Wilson, A.; Stones-Havas, S.; Cheung, M.; Sturrock, S.; Buxton, S.; Cooper, A.; Markowitz, S.; Duran, C. Geneious Basic: An integrated and extendable desktop software platform for the organization and analysis of sequence data. Bioinformatics 2012, 28, 1647-1649. [CrossRef] [PubMed]

23. Schloss, P.D.; Westcott, S.L.; Ryabin, T.; Hall, J.R.; Hartmann, M.; Hollister, E.B.; Lesniewski, R.A.; Oakley, B.B.; Parks, D.H.; Robinson, C.J. Introducing mothur: Open-source, platform-independent, community-supported software for describing and comparing microbial communities. Appl. Environ. Microbiol. 2009, 75, 7537-7541. [CrossRef] [PubMed]

24. Edgar, R.C.; Haas, B.J.; Clemente, J.C.; Quince, C.; Knight, R. UCHIME improves sensitivity and speed of chimera detection. Bioinformatics 2011, 27, 2194-2200. [CrossRef] [PubMed]

25. Lee, J.H.; Suryaningtyas, I.T.; Yoon, T.H.; Shim, J.M.; Park, H.; Kim, H.W. Transcriptomic analysis of the hepatopancreas induced by eyestalk ablation in shrimp, Litopenaeus vannamei. Comp. Biochem. Physiol. Part D Genom. Proteom. 2017, 24, 99-110. [CrossRef] [PubMed]

26. Diaz, J.I.; Fusaro, B.; Longarzo, L.; Coria, N.R.; Vidal, V.; D'Amico, V.; Barbosa, A. Gastrointestinal helminths of Adélie penguins (Pygoscelis adeliae) from Antarctica. Polar Res. 2016, 35, 28516. [CrossRef]

27. Valentini, A.; Pompanon, F.; Taberlet, P. DNA barcoding for ecologists. Trends Ecol. Evol. 2009, 24, 110-117. [CrossRef]

28. Lim, N.K.; Tay, Y.C.; Srivathsan, A.; Tan, J.W.; Kwik, J.T.; Baloğlu, B.; Meier, R.; Yeo, D.C. Next-generation freshwater bioassessment: eDNA metabarcoding with a conserved metazoan primer reveals species-rich and reservoir-specific communities. R. Soc. Open Sci. 2016, 3, 160635. [CrossRef]

29. Epp, L.S.; Boessenkool, S.; Bellemain, E.P.; Haile, J.; Esposito, A.; Riaz, T.; Erseus, C.; Gusarov, V.I.; Edwards, M.E.; Johnsen, A. New environmental metabarcodes for analysing soil DNA: Potential for studying past and present ecosystems. Mol. Ecol. 2012, 21, 1821-1833. [CrossRef]

30. Wang, W.Y.; Srivathsan, A.; Foo, M.; Yamane, S.K.; Meier, R. Sorting specimen-rich invertebrate samples with cost-effective NGS barcodes: Validating a reverse workflow for specimen processing. Mol. Ecol. Resour. 2018, 18, 490-501. [CrossRef]

31. Hebert, P.D.; DeWaard, J.R.; Zakharov, E.V.; Prosser, S.W.; Sones, J.E.; McKeown, J.T.; Mantle, B.; La Salle, J. A DNA “barcode blitz": Rapid digitization and sequencing of a natural history collection. PLoS ONE 2013, 8, e68535. [CrossRef] 
32. Leray, M.; Yang, J.Y.; Meyer, C.P.; Mills, S.C.; Agudelo, N.; Ranwez, V.; Boehm, J.T.; Machida, R.J. A new versatile primer set targeting a short fragment of the mitochondrial COI region for metabarcoding metazoan diversity: Application for characterizing coral reef fish gut contents. Front. Zool. 2013, 10, 34. [CrossRef] [PubMed]

33. Albaina, A.; Aguirre, M.; Abad, D.; Santos, M.; Estonba, A. $18 \mathrm{~S}$ rRNA V9 metabarcoding for diet characterization: A critical evaluation with two sympatric zooplanktivorous fish species. Ecol. Evol. 2016, 6, 1809-1824. [CrossRef]

34. Cherel, Y.; Koubbi, P.; Giraldo, C.; Penot, F.; Tavernier, E.; Moteki, M.; Ozouf-Costaz, C.; Causse, R.; Chartier, A.; Hosie, G. Isotopic niches of fishes in coastal, neritic and oceanic waters off Adélie land, Antarctica. Polar Sci. 2011, 5, 286-297. [CrossRef]

35. Vestheim, H.; Jarman, S.N. Blocking primers to enhance PCR amplification of rare sequences in mixed samples-A case study on prey DNA in Antarctic krill stomachs. Front. Zool. 2008, 5, 12. [CrossRef] [PubMed]

36. Liu, C.; Qi, R.-J.; Jiang, J.-Z.; Zhang, M.-Q.; Wang, J.-Y. Development of a blocking primer to inhibit the PCR amplification of the $18 \mathrm{~S}$ rDNA sequences of Litopenaeus vannamei and its efficacy in Crassostrea hongkongensis. Front. Microbiol. 2019, 10, 830. [CrossRef] [PubMed]

37. Hernández-Orts, J.S.; Scholz, T.; Brabec, J.; Kuzmina, T.; Kuchta, R. High morphological plasticity and global geographical distribution of the Pacific broad tapeworm Adenocephalus pacificus (syn. Diphyllobothrium pacificum): Molecular and morphological survey. Acta Trop. 2015, 149, 168-178. [CrossRef] [PubMed]

38. Golemansky, V. Coccidian parasites (Apicomplexa) of penguins (Pygoscelis ssp.) from Livingston Island and King George Island, the Antarctic. Pol. Polar Res. 2011, 32, 263-268. [CrossRef]

39. De Paula, A.A.; Ott, P.H.; Tavares, M.; Santos, R.A.; Silva-Souza, A.T. Host-parasite relationship in Magellanic Penguins (Spheniscus magellanicus) during their long northward journey to the Brazilian coast. Polar Biol. 2020, 43, 1261-1272. [CrossRef]

40. Vidal, V.; Ortiz, J.; Diaz, J.I.; de Ybañez, M.R.; Amat, M.; Palacios, M.; Benzal, J.; Valera, F.; De la Cruz, C.; Motas, M. Gastrointestinal parasites in Chinstrap Penguins from Deception Island, South Shetlands, Antarctica. Parasitol. Res. 2012, 111, 723-727. [CrossRef]

41. Bagrade, G.; Králová-Hromadová, I.; Bazsalovicsová, E.; Radačovská, A.; Kołodziej-Sobocińska, M. The first records of Spirometra erinaceieuropaei (Cestoda: Diphyllobothriidae), a causative agent of human sparganosis, in Latvian wildlife. Parasitol. Res. 2021, 120, 365-371. [CrossRef]

42. Ainley, D.G.; Wilson, P.R.; Barton, K.J.; Ballard, G.; Nur, N.; Karl, B. Diet and foraging effort of Adélie penguins in relation to pack-ice conditions in the southern Ross Sea. Polar Biol. 1998, 20, 311-319. [CrossRef]

43. Volkman, N.J.; Presler, P.; Trivelpiece, W. Diets of Pygoscelid Penguins at King George Island, Antarctica. Condor 1980, 82, 373-378. [CrossRef]

44. Ghigliotti, L.; Ferrando, S.; Carlig, E.; Di Blasi, D.; Gallus, L.; Pisano, E.; Hanchet, S.; Vacchi, M. Reproductive features of the Antarctic silverfish (Pleuragramma antarctica) from the western Ross Sea. Polar Biol. 2017, 40, 199-211. [CrossRef]

45. Vacchi, M.; La Mesa, M.; Dalu, M.; Macdonald, J. Early life stages in the life cycle of Antarctic silverfish, Pleuragramma antarcticum in Terra Nova Bay, Ross Sea. Antarct. Sci. 2004, 16, 299-305. [CrossRef]

46. Watanabe, Y.Y.; Takahashi, A. Linking animal-borne video to accelerometers reveals prey capture variability. Proc. Natl. Acad. Sci. USA 2013, 110, 2199-2204. [CrossRef] [PubMed]

47. Cherel, Y. Isotopic niches of emperor and Adélie penguins in Adélie Land, Antarctica. Mar. Biol. 2008, 154, 813-821. [CrossRef]

48. Vacchi, M.; DeVries, A.L.; Evans, C.W.; Bottaro, M.; Ghigliotti, L.; Cutroneo, L.; Pisano, E. A nursery area for the Antarctic silverfish Pleuragramma antarcticum at Terra Nova Bay (Ross Sea): First estimate of distribution and abundance of eggs and larvae under the seasonal sea-ice. Polar Biol. 2012, 35, 1573-1585. [CrossRef]

49. Offredo, C.; Ridoux, V.; Clarke, M.R. Cephalopods in the diets of Emperor and Adelie penguins in Adelie Land, Antarctica. Mar. Biol. 1985, 86, 199-202. [CrossRef]

50. Cavallo, C.; Chiaradia, A.; Deagle, B.E.; McInnes, J.C.; Sánchez, S.; Hays, G.C.; Reina, R.D. Molecular Analysis of Predator Scats Reveals Role of Salps in Temperate Inshore Food Webs. Front. Mar. Sci. 2018, 5, 381. [CrossRef]

51. Sala, A.; Azzali, M.; Russo, A. Krill of the Ross Sea: Distribution, abundance and demography of Euphausia superba and Euphausia crystallorophias during the Italian Antarctic Expedition (January-February 2000). Sci. Mar. 2002, 66, 123-133. [CrossRef]

52. Azzali, M.; Leonori, I.; De Felice, A.; Russo, A. Spatial-temporal relationships between two euphausiid species in the Ross Sea. Chem. Ecol. 2006, 22, S219-S233. [CrossRef]

53. Meyer, B. The overwintering of Antarctic krill, Euphausia superba, from an ecophysiological perspective. Polar Biol. 2012, 35, 15-37. [CrossRef]

54. Ainley, D. The Adélie Penguin; Columbia University Press: New York, NY, USA, 2002.

55. Forcada, J.; Trathan, P.N.; Reid, K.; Murphy, E.J.; Croxall, J.P. Contrasting population changes in sympatric penguin species in association with climate warming. Glob. Chang. Biol. 2006, 12, 411-423. [CrossRef]

56. Croxall, J.P.; Reid, K.; Prince, P.A. Diet, provisioning and productivity responses of marine predators to differences in availability of Antarctic krill. Mar. Ecol. Prog. Ser. 1999, 177, 115-131. [CrossRef]

57. William, R.F.; Eileen, E.H. A predator's perspective on causal links between climate change, physical forcing and ecosystem response. Mar. Ecol. Prog. Ser. 2003, 265, 1-15.

58. Quetin, L.B.; Ross, R.M. Environmental variability and its impact on the reproductive cycle of antarctic krill1. Am. Zool. 2015, 41, 74-89. [CrossRef] 